\title{
Isolated Intraventricular Haemorrhage Following Evacuation of Chronic- subacute Haemorrhage: A Case Report
}

\author{
Kronik-subakut Subdural Hematomun Bosaltılmasını Takiben \\ Gelişen Izole Intraventriküler Kanama: Bir Olgu Sunumu
}

\author{
(1) Zahir Kızılay ${ }^{1}$, (1) Yavuz Selim Aydın², (1) Ali Yılmaz ${ }^{1}$, (1) Abdullah Topçu ${ }^{1}$, (1) Osman Berber ${ }^{1}$, (1) Murat Özcan Yay ${ }^{1}$ \\ ${ }^{1}$ Aydın Adnan Menderes University Faculty of Medicine, Department of Neurosurgery, Aydın, Turkey \\ ${ }^{2}$ Uşak State Hospital, Clinic of Neurosurgery, Uşak, Turkey
}

Keywords

Chronic subdural haemorrhage, complication, intra-ventricular haemorrhage

Anahtar Kelimeler

Kronik subdural kanama, komplikasyon, intraventriküler kanama

Received/Geliş Tarihi : 07.11.2016

Accepted/Kabul Tarihi : 28.11.2017

doi:10.4274/meandros.galenos.2017.54154

Address for Correspondence/Yazışma Adresi: Zahir Kızılay MD,

Aydın Adnan Menderes University Faculty of Medicine, Department of Neurosurgery, Aydın, Turkey

Phone : +902564441256

E-mail : zahir.kizilay@adu.edu.tr

ORCID ID: orcid.org/0000-0002-2021-0406

(C) Meandros Medical and Dental Journal, Published by Galenos Publishing House.

This is article distributed under the terms of the

Creative Commons Attribution NonCommercial 4.0

International Licence (CC BY-NC 4.0).

\begin{abstract}
Chronic subdural haemorrhage is commonly encountered in the elderly. However, the outcomes of surgery for chronic subdural haemorrhage are frequently benign; surgeons may sometimes encounter unexpected complications after evacuation of chronic subdural haemorrhage as isolated intra-ventricular haemorrhage. A few hypotheses have been developed to explain this phenomenon. Here, we present a case report and explain this phenomenon with new a hypothesis.
\end{abstract}

Öz

Kronik subdural kanama, sıklıkla yaşılıarda karşılaşılır. Kronik subdural kanamanın cerrahi sonuçları sıklıkla iyi olmasına karşın, bazen cerrahlar subdural kanamanın boşaltılmasını takiben izole intraventriküler kanama gibi beklenmeyen komplikasyonlarla da karşılaşabilirler. Bu fenomeni açıklamaya yönelik birkaç hipotez geliştirildi. Bu çalışmada bir olgu sunumu yapılarak yeni bir hipotezle bu fenomen açıklanmıştır.

\section{Introduction}

Chronic subdural hematoma (CSH) is an abnormal collection of liquid blood between the dura mater and the arachonoid mater which is frequently encountered in neurosurgical conditions, especially in the elderly $(1,2)$. Various ethological factors have been identified but head trauma is the most common (3). Surgeons may encounter unwanted post-operative complications such as cerebral edema, tension pneumocephalus, recurrent hematoma, seizure, failure of the brain to re-expand (3-5). But intra-ventricular hemorrhage (IVH) after evacuation of $\mathrm{CSH}$ is a rarely encountered complication. We report a patient who had an isolated IVH which was identified following evacuation of left frontotemporaparietal CSH. 


\section{Case Report}

A 72-year-old female patient was referred to the emergency room with right hemipharesis and two days of complaints of confusion. Right hemiparesis, lack of orientation and pathological reflexes were identified in her first neurological examination. Also, we learned from her children that she had suffered a head trauma three weeks previously and she did not take an anticoagulant thearpy. Cranial computed tomography (CT) and cranial magnetic resonance imaging (MRI) were performed, and chronic-subacute subdural hemorrhage and septations with 1.2 centimeter midline shift were identified on CT (Figure 1A) and on MRI (Figure 1B). We decided to perform urgent surgery via burr hole exploration. Informed patient consent was obtained from her guardians. The patient's body and head were laid on her right side and then burr hole was made in the left frontal bone with a high-speed drill under local anesthesia and intravenous sedation. The external membrane of the chronic subdural hemorrhage at the left frontal bone was coagulated with bipolar and then opened. Compressive hemorrhage in the subdural space leaked out on its own. Frontal feeding catheter was placed in the subdural space. The subdural space was washed with saline. The frontal part of the internal membrane of the CSH was opened under the operating microscope with a bipolar. The frontal burr hole feeding catheter was left in place. The feeding catheter was connected to a closed drainage system. A cranial CT was performed on the $3^{\text {rd }}$ postoperative day (Figure 2A) and then the feeding

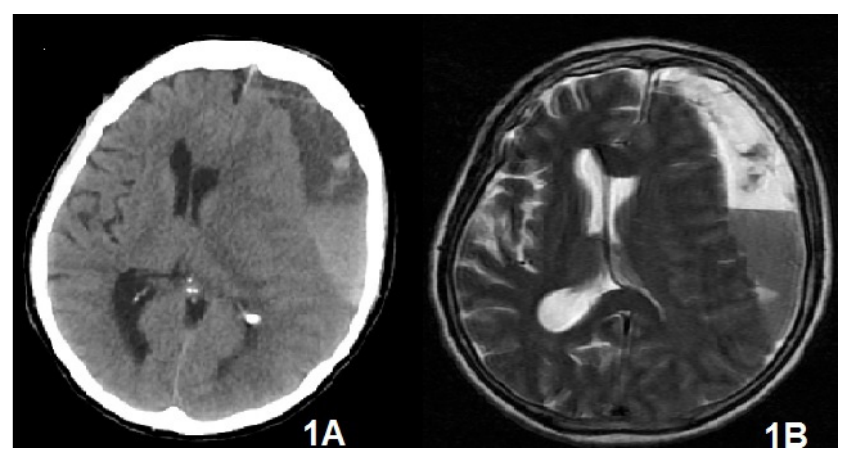

Figure 1. Preoperative axial cranial computed tomography: There was no hemorrhage in the lateral ventricular before surgery (1A), Preoperative T2 weighted axial cranial magnetic resonance imaging: Left frontotemporoparietal subacutechronic subdural hemorrhage with 1.2 centimeters midline shift (1B) catheter was withdrawn. Bilateral IVH was observed in the occipital horns of the lateral ventricular, but there was no midline shift. The second cranial CT was performed on the $6^{\text {th }}$ day of post-operative (Figure 2B). We observed hemorrhage in the occipital horn of the lateral ventricular again, but there was no acute hydrocephalus. The patient was discharged on the $7^{\text {th }}$ day after surgery with complete recovery.

\section{Discussion}

Different bleeding paterns have been definied after evacuation of subdural hemorrage in the literature. Cortical hyperemia beneath the hematoma, subarachnoid hemorrhage (SAH), supratenterial intracerebral, intra-ventricular, and rometo cerebellar hemorrhages are rarely reported (6). In a large series of 1,000 cases $\mathrm{CSH}, 4$ cases of post-operative intracranial bleeding were described (4\%) (7). Rusconi et al. (6), have been reported unusual postoperative hemorrhagic events with an incidence of $0.78 \%$ (3 patients) (6). Other authors have been reported an incidence range between $0.2-4 \%(8,9)$. Overdrainage, rapid brain decompration and shift of the intracranial contents, massive cerebrospinal fluid (CSF) loss, veneous outflow impairment and vascular dysregulation with blood flow increas, are the mechanisms currently debated (6).

Two possible mechanisms have been suggested to explain isolated IVH after evacuation of CSH. The first of these was suggested by Cook et al. (10) Their hypothesis was that elderly patients with physiological aging of the cerebral vascular tree may not tolerate a

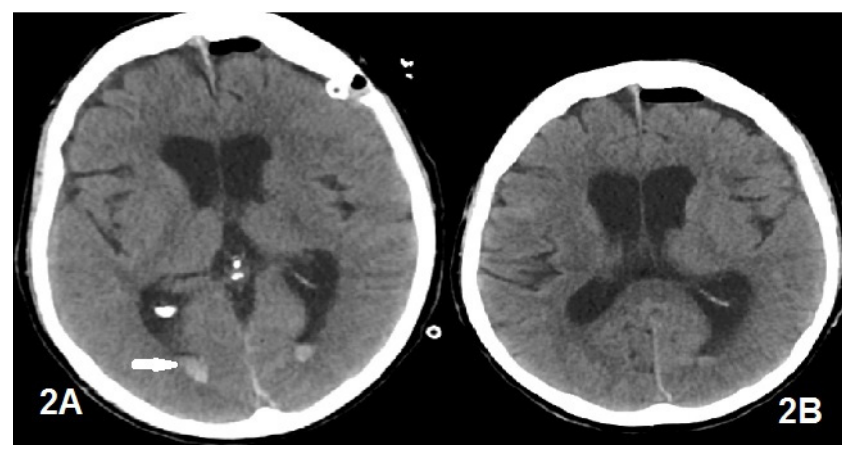

Figure 2. First axial cranial computed tomography (CT) after surgery: Midline shift recovered but a new intraventricular hemorrhage was detected (white arrow) (2A), second axial cranial CT after surgery: Neither increase in intraventricular hemorrhage nor development of hydrocephalus were detected (2B) 
sudden restoration of normal perfusion pressure in areas of deranged cerebral vascular autoregulation (5). The second hypothesis was suggested by Savardekar and Salunke (5). They hypothesized that after sudden decompression of the brain, the differential expansile qualities of solid (brain) and liquid (CSF) components of the cranium may result in mechanical stress at the interface. It may then cause rupture of the engorged subependymal veins (2). In addition to these, Muneza et al. (3) suggested that fragile cerebral vessels, direct vascular damage and a shift of the midline structures might be contributory factors for IVH (4).

Our case is similar to the literature. The patient was elderly, and she had a subacute-CSH which included a 1.2 centimeter midline shift. CSH was evacuated via burr holes under local anesthesia and intravenous sedation. We identified an isolated hemorrhage in the lateral ventricular occipital horns on the $3^{\text {rd }}$ day after surgery. Our opinion is that when evacuation of $\mathrm{CSH}$ is started suddenly it may cause rapid correction of midline shift. Rapid correction of the midline shift and rapid movement of the brain may lead to vascular shearing owing to mechanical stress especially on coroid plexus vessel. The elderly may be susceptible to this vascular shear due to vascular aging. Our hypothesis seems to be supported by two hypotheses. In addition to these, the other causes of isolated IVH include coagulation disorders, pituitary apoplexy, sickle cell anemia, drug consumption and vasculitides, but none of these was demonstrated. In our opinion is that, isolated IVH is a different event and may not be explained with vascular self-adjustment which was suggested to explain for intracerebral hemorrhage and SAH following removal of the subdural hemorrhage.

Multiple surgical techniques have been defined in tle literature for evacuation of chronic subdural hemorrhage, including twist drill craniostomy, burrhole craniostomy, and craniotomy. And various complication have been reported related with surgical techniques (11). In our case, we have prefered the burr hole craniostomy for evacuation of subacut-chronic subdural hemorrhage under the local anesthesia and intravenous sedation. Our opinion is that gradual and graded evacuation can be archived by covering of the burr hole with a sponge or a cotonoid immedietly after opening the dura and the outher membrane. And than, A sponge or a cotonoid can be removed intermittent. By that mechanism, evacuation of subdural hemorrhage can be controlled and slowed down in a controlled way and this procedure can be continued till the subdural pressures equalize with the atmospheric pressures. This gradual and graded evacuation of subdural hemorrhage may decrease the mechanical stres on coroid plexus vessels.

In conclusion, although isolated IVH is rarely encountered, surgeons should keep it in mind because IVH may result in lethal complications following evacuation of $\mathrm{CSH}$. Clinical awareness of this complication is essential. We suggest that slow and gradual decompression may protect the patient from this complication. Aging, amount of midline shift and speed of correction of midline shift may be contributory factors. Causative factors have not yet been clearly identified. Therefore, further investigations and large patient series are needed to clarify this phenomenon.

\section{Ethics}

Informed Consent: Informed patient consent was obtained from her guardians.

Peer-review: Externally and internally peerreviewed.

\section{Authorship Contributions}

Concept: Z.K., Y.S.A., A.Y., Design: Z.K., A.Y., Supervision: Z.K., A.T., Data Collection or Processing: Z.K., O.B., M.Ö.Y., Analysis or Interpretation: Z.K., A.T., A.Y., Literature Search: Z.K., O.B., A.T., Writing: Z.K., Critical Review: Z.K., A.T., A.Y.

Conflict of Interest: There is no conflict of interest between the authors.

Financial Disclosure: No financial support has been received from anywhere for this article.

\section{References}

1. Almenawer SA, Farrokhyar F, Hong C, Alhazzani W, Manoranjan B, Yarascavitch $B$, et al. Chronic subdural hematoma management: a systematic review and meta-analysis of 34,829 patients. Ann Surg 2014; 259: 449-57.

2. Liu W, Bakker NA, Groen RJ. Chronic subdural hematoma: a systematic review and meta-analysis of surgical procedures. J Neurosurg 2014; 121: 665-73.

3. Muneza S, Rasoloherimampiononiaina MR, Nduwamariya MJ. Postoperative intracerebral and intraventricular hemorrhages following removal of a chronic subdural hematoma. J Clin Neurosci 2009; 16: 1346-8.

4. Kim JK, Kim SW, Kim SH. Intracerebral hemorrhage following evacuation of a chronic subdural hematoma. J Korean Neurosurg Soc 2013; 53: 108-11. 
5. Savardekar AR, Salunke P. Subependymal hemorrhage following drainage of chronic subdural hematoma: Probable causative mechanisms and prevention strategies. J Neurosci Rural Pract 2015; 6: 252-4.

6. Rusconi A, Sangiorgi S, Bifone L, Balbi S. Infrequent Hemorrhagic Complications Following Surgical Drainage of Chronic Subdural Hematomas. J Korean Neurosurg Soc 2015; 57: 379-85.

7. Gelabert-González M, Iglesias-Pais M, García-Allut A, MartínezRumbo R. Chronic subdural haematoma: surgical treatment and outcome in 1000 cases. Clin Neurol Neurosurg 2005; 107: 223-9.

8. Dinc C, Iplikcioglu AC, Bikmaz K, Navruz Y. Intracerebral haemorrhage occurring at remote site following evacuation of chronic subdural haematoma. Acta Neurochir (Wien) 2008; 150: 497-9.

9. Mori K, Maeda M. Surgical treatment of chronic subdural hematoma in 500 consecutive cases: clinical characteristics, surgical outcome, complications, and recurrence rate. Neurol Med Chir (Tokyo) 2001; 41: 371-81.

10. Cook AW, Browder EJ, Carter WB. Cerebral swelling and ventricular alterations following evacuation of intracranial extracerebral hematoma. J Neurosurg 1962; 19: 419-23.

11. Ducruet AF, Grobelny BT, Zacharia BE, Hickman ZL, DeRosa $\mathrm{PL}$, Andersen $\mathrm{KN}$, et al. The surgical management of chronic subdural hematoma. Neurosurg Rev 2012; 35: 155-69. 